\title{
ACRL officers for 1989-90
}

\section{The official ACRL election results.}

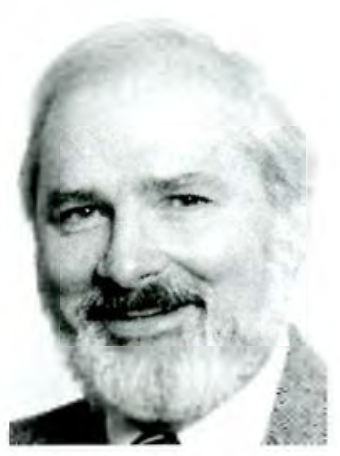

William A. Moffett

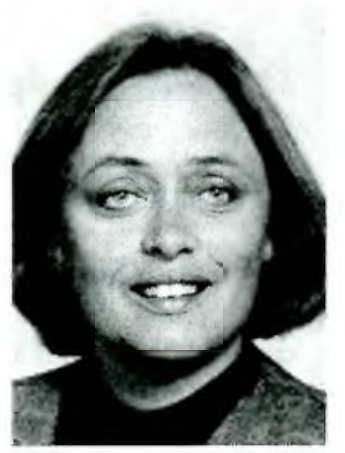

Barbara J. Ford

Willuam A. Moffett, director of libraries at Oberlin College (Oberlin, OH 44074), is the fiftysecond president of the Association of College and Research Libraries. During his one-year term of office, he will preside over the ACRL Board of Directors and the ACRL Executive Committee. He will chair the ACRL Conference Program Planning Committee for the 1990 Annual Conference in Chicago and will plan ACRL's major program at the conference.

As president of the division, Moffett will represent ACRL on the ALA Dallas Conference Program Planning Committee and the ALA Planning and Budget Assembly. He will also represent ACRL and ALA in their relations with other organizations. Moffett served as chair of the ACRL College Libraries Section in 1984-85 and was instrumental in establishing the CLS National Advisory Council in 1986. He has also served as chair of the RBMS Security Committee, and has been a member of the Publications and Academic/Research Librarian of the Year Committees.

Barbara J. Ford, associate director for public services at the Trinity University Library (San Antonio, TX 78284), has been elected vice-president/president-elect of the Association of College

and Research Libraries. The 1989 election results showed 1,555 votes for Ford and 1,158 for Patricia Wand, assistant university librarian for public services at the University of Oregon (Eugene, OR 97403).

As vice-president/president-elect of ACRL, Ford will serve on the ACRL Board of Directors and the ACRL Executive Committee. She will chair the ACRLConference Program Planning Committee for the 1991 Annual Conference in Atlanta. She will represent ACRL on the ALA Appointments Committee and the ALA Conference Program Planning Committee for the 1991 Conference. At the end of the 1990 Annual Conference she will become ACRL's fifty-third president.

Ford served as chair of the ACRL Academic Status Committee in 1983-84 and just completed a term on ALA Council (1985-89). She was chair of the ACRL/ULS Conference Program Committee in 1985-86. She has also been active in the Texas Library Association, the Special Libraries Association, IFLA, and ALISE.

The results of the ACRL elections follow. For each position, the elected candidate is given first, with the number of votes earned given in parentheses.

\section{Anthropology and Sociology Section}

Vice-Chair/Chair-Elect: CherYL C. Kugrer (55); Robert B. Marks Ridinger (46).

Secretary: ANN L. Wood (65); Gregory A. Finnegan (38).

Member-at-Large: MaRY M. KoenIG (66); Anita Garey (35).

\section{Art Section}

Vice-Chair/Chair-Elect: JoAn D. Kunseuman (95); Jeffrey L. Horrell (65). 
Secretary: Micheline Nelson (83); Sandra Mooney (69).

\section{Asian and African Section}

Vice-Chair/Chair-Elect: Joanne M. ZELLERS (70); Michael W. Albin (43).

Member-at-Large: Diane E. Perushex (53); Bonnie L. Wright (4I).

Member-at-Large: Chrus Fustrup (68); Ray P. Boylan (52).

\section{Bibliographic Instruction Section}

Vice-Chair/Chair-Elect: Betsy WILson (582); Ellen Meltzer (339).

Secretary: Randall B. Hensley (450); Sharon J. Van Der Laan (427).

Member-at-Large: BonnIE GraTch (626); John W. Collins III (270).

\section{College Libraries Section}

Vice-Chair/Chair-Elect: Mrchatu D. Kathman (287); David J. Norden (174).

Secretary: Nancy Magnuson (259); Pamela Snelson (194).

Member-at-Large: Sherrie S. Bergman (247); Larry J. Frye (215).

\section{Community and Junior College Libraries Section}

Vice-Chair/Chair-Elect: MariLyN MCDonaud (107); Madison Mosley Jr. (91).

Secretary: Camila A. Alire (104); Lynette Anderson (90).

\section{Education and Behavioral Sciences Section}

Vice-Chair/Chair-Elect: TARA L. Fulton (179); Dorothy Persson (171).

Secretary: Jo ANn CakR (204); Barbara Celone (142).

\section{Law and Political Science Section}

Vice-Chair/Chair-Elect: MARTA A. LANGE (85); Ronald J. Heckart (82). (75).

Secretary: Caroline TibBetrs (86); Barbara Burg

Member-at-Large: Robert Schruek (82); Charles D.G. Spornick (72).

\section{Rare Books and Manuscripts Section}

Vice-Chair/Chair-Elect: DANiEL Traister (300); David S.Zeidberg(195).
Secretary: Jackie M. Dooley (298); Romaine Ahlstrom (173).

Member-at-Large: Pat Bozeman (256); Martin Antonetti (219).

\section{Science and Technology Section}

Vice-Chair/Chair-Elect: Couleen Power (219); Robert Michaelson (217).

Secretary: Caroline D. HaRnly (273); Karen Feeney (156).

\section{Slavic and East European Section}

Vice-Chair/Chair-Elect: NiNA G. SHAPIRo (58); write-in (4),

Member-at-Large: Molly Moldoy (47); Janet I. Crayne (17).

\section{University Libraries Section}

Vice-Chair/Chair-Elect: Janice T. Koyama (999); Kent Hendrickson (768).

\section{Western European Specialists Section}

Vice-Chair/Chair-Elect: Eva M. SARTORI (14I); Richard Ring (68). (78).

Secretary: John Cullaks (123); Leona L. Wise

Member-at-Large: Danielle Mihram (111); Richard D. Hacken (89).

\section{Women's Studies Section}

Vice-Chair/Chair-Elect: Patricia A. KreItz (93); Betty J. Glass (89).

Secretary: Cheryl Knott Malone (114); Bernice K. Lacks (66).

Member-at-Large: JACQueLrN MARIE (125); Nancy Luikart (54).

\section{Corrections}

The article in the July/August issue, "Developing college library leaders of tomorrow," was a collaborative and equal effort by the five members of the panel of college library directors: Mignon Adams, Anne Commerton, Larry Hardesty, Michael Kathman, and Jacquelyn Morris.

The Publications listing for Cartolai, Illuminators, and Printers in Fifteenth-Century Italy: The Evidence of the Ripoli Press in the May 1989 issue of $C \& R L$ News erroneously gave the author's name as "Roscoe A. Rouse"; the author's correct name is Richard H. Rouse. Cost of the book - not mentioned in the original listing - is $\$ 20.00$. 